\title{
PENGARUH BUDAYA ORGANISASI TERHADAP IKLIM ORGANISASI DAN KEPUASAN KERJA (Kajian pada Karyawan Koperasi Grup Cipta Sejahtera)
}

\author{
Rakhmadi Widyo Aryanto ${ }^{1}$, Endang Siti Astuti², Srikandi Kumadji ${ }^{3}$ \\ Fakultas Ilmu Administrasi, Universitas Brawijaya Malang \\ Program Pasca Sarjana, Universitas Brawijaya \\ Email: aldhita.gresentya@gmail.com ${ }^{1}$,endangsiti@ub.ac.id ${ }^{2}$,Srikandi_K@ub.ac.id ${ }^{3}$
}

\begin{abstract}
Background of the research is that paradigm emerged employee turn-over ratio in koperasi is low, even though compared with the other organizational. Set from that idea, this research entitled "Organizational Culture Influence towards Organizational Climate and Job satisfaction (A Research on Cipta Sejahtera Koperasi Group Employee)" aim on organizational culure influence towards organizational climate and job satisfaction, and organizational climate influence towards job satisfaction. This research locate on Cipta Sejahtera Koperasi, categorise in explanatory research with qualitative methods and descriptive approach. Data collection techniques use quistionare that is shared towards 60 (sixty) employee of Cipta Sejahtera Grup koperasi which vary on age, education, gender, work period. Result of the resarch inidcates that (1) organizational culture have significant influence in organizational climate, (2) organizational climate have not significant influence towards job satisfaction, (3) and organizational culture have significant influence towards job satisfaction.
\end{abstract}

Keywords: Organizational Culture, Organizational Climate, Job Satisfaction.

\begin{abstract}
ABSTRAK
Latar belakang penelitian ini adalah karena adanya suatu paradigma yang mana terjadi di koperasi yaitu tingkat turn-over dari karyawan rendah, padahal jika di bandingkan dengan perusahaan lain baik dari segi upah/gaji maupun kesejahteraan koperasi memberikan lebih sedikit dibandingkan dengan organisasi yang lain yang sejenis. Berangkat dari pemikiran tersebut penelitian dengan judul "Pengaruh Budaya Organisasi terhadap Iklim Organisasi dan Kepuasan Kerja" ini bertujuan untuk mengetahui pengaruh budaya organisasi terhadap iklim organisasi dan kepuasan kerja, dan pengaruh iklim organisasi terhadap kepuasan kerja. Penelitian yang berlokasi di Koperasi Cipta Sejahtera ini termasuk dalam penelitian eksplanatori dengan menggunakan metode kualitatif dengan pendekatan deskriptif. Pengambilan data berupa kuisioner yang disebarkan kepada 60 (enam puluh) karyawan grup koperasi Cipta Sejahtera, yang memiliki keaneka ragaman baik dari segi usia, pendidikan, jenis kelamin, dan masa kerja. Hasil penelitian menunjukan (1) budaya organisasi berpengaruh signifikan terhadap iklim organisasi, (2) iklim organisasi tidak berpengaruh signifikan terhadap kepuasan kerja, dan (3) budaya organisasi berpengaruh signifikan terhadap kepuasan kerja.
\end{abstract}

Kata Kunci: Budaya Organisasi, Iklim Organisasi, Kepuasan Kerja. 


\section{PENDAhuluan}

Krisis ekonomi yang dimulai awal tahun 1997 telah membawa keterpurukan bagi kemunduran pertumbuhan ekonomi Indonesia. Pada era tahun 1986-1996 pertumbuhan sektor industri mencapai $20,3 \%$, namun pada tahun 1997-2006 rata-rata tingkat pertumbuhan sector industri tinggal $6,3 \%$. Selain penurunan sector industri, ditandai pula dengan meningkatnya angka kemiskinan yang mencapai 39 juta jiwa atau setara dengan jumlah penduduk Malaysia, dikutip dari harian Kompas, 16 Agustus 2007. Salah satu alternatif untuk bangkit dari keterpurukan ekonomi adalah dengan meningkatkan kualitas pengelolaan koperasi secara terencana, terarah, intensif, efektif dan efisien karena koperasi merupakan salah satu pilar ekonomi bangsa. Koperasi berdasarkan etimologi bahasanya berasal dari dua kata penyusun yaitu $C o$ yang berarti bersama dan Operation yang berarti kerja, sehingga ketika kedua kata tersebut digabungkan menjadi Cooperation yang berati bekerja sama.

Koperasi hakikatnya merupakan refleksi dari nilai-nilai budaya Indonesia, yang mana mempunyai sikap fleksibilitas, tenggang rasa, dan nilai kekeluargaan yang lebih jika dibandingkan dengan bank konvensional pada saat ini. Fleksibilitas adalah kemudahan dalam proses pengumpulan atau peminjaman dana.Koperasi merupakan suatu lembaga keuangan mikro yang sangat penting dalam pemenuhan kebutuhan primer bagi masyarakat, karena pada lembaga keuangan mikro tersebutlah terjadi proses pengumpulan dana dan penyaluran dana dari dan untuk masyarakat.

Beragamnya lembaga atau organisasi bisnis yang berkecimpung dalam peminjaman dana bagi masyarakat saat ini yang syarat dengan promosi dan iming-iming yang menggiurkan namun demikian selain tidak fleksibel juga menggunakan sistem perhitungan bunga pinjaman yang memberatkan masyarakat. Kondisi yang seperti itu, keberadaan koperasi yang bergerak di peminjaman uang dan modal, memberikan peluang kepada masyarakat, sebagai salah satu alternatif. Terkait dengan hal tersebut ada baiknya koperasi mempunyai suatu bentuk improvisasi baik sistim maupun bentuk program yang ditawarkan kepada masyarakat. Dengan demikian masyarakat khususnya yang menjadi nasabah koperasi diharapkan merasa mendapatkan manfaat lebih. Disamping harapan akan keberlangsungan hidup dari koperasi itu sendiri terjamin. Uraian tersebut dapat pula sebagai petunjuk akan peran anggota organisasi yang menjalankan koperasi agar tetap terus berjalan, sehingga tujuan koperasi tercapai, dan performa dari tiap anggotannya dapat maksimal. Hal tersebut sangat ditentukan oleh Budaya organisasi, Iklim Organisasi, dan Kepuasan Kerja Pegawai atau Anggota Koperasi.

\section{KAJIAN PUSTAKA}

\section{a. Budaya Organisasi}

Budaya merupakan suatu hal yang tidak dapat lepas dari perilaku manusia karena budaya sangat identik dengan sikap dan perilaku suatu masyarakat atau organisasi. Budaya sebenarnya berasal dari disiplin ilmu antropologi, dan pada sekitar tahun 1979 kata budaya ini seringkali dikaitkan dengan organisasi (Hamidah, dkk, 2001). Budaya organisasi adalah suatu sistem pemahaman atau cara pandang dalam bertindak yang dimengerti dan menjadi pegangan seluruh karyawan yang membedakan suatu organisasi dengan organisasi lain. Budaya organisasi menjadi suatu hal yang sangat penting karena menyangkut nilai-nilai tradisi dan perilaku yang menjadi pedoman karyawan atau anggota dalam suatu organisasi.

Menurut Robins (2002), proses pembentukan budaya organisasi dimulai dari pemikiran pendirinya, yang kemudian menentukan arah kriteria seleksi anggota baru organisasi oleh manajemen puncak, melalui sosialisasi. Budaya organisasi dapat dikatakan juga terbentuk secara tidak langsung oleh tuntutan fungsionalnya, hal tersebut dapat diartikan dikarenakan terjadi interaksi unsurunsur pembentuknya Budaya Organisasi mempunyai suatu fungsi yang mana mempunyai tujuan yang mewakili tujuan dari masing-masing unsur pembentuknya. Sedangkan fungsi budaya organisasi, diantaranya:

1. Budaya mempunyai suatu peran menetapkan tapal batas, artinya budaya;

2. Menciptakan pembedaan yang jelas antara satu organisasi dan yang lain;

3. Budaya membawa suatu rasa identitas bagi anggota-anggota organisasi;

4. Budaya mempermudah timbulnya komitmen pada sesuatu yang lebih luas dari pada kepentingan diri pribadi seseorang; 
5. Budaya meningkatkan kemantapan sistem social;

6. Budaya berfungsi sebagai mekanisme pembuat makna dan kendali yang memandu dan membentuk sikap serta perilaku karyawan.

\section{b. Iklim Organisasi}

Iklim organisasi adalah suatu rangkaian deskripsi dari karakteristik organisasi yang membedakan sebuah organisasi dengan organisasi lainnya yang mengarah pada persepsi atau pemahaman cara pandang dari masing - masing anggota dalam memandang organisasi. James dan Jones dalam Toulson dan Smith (1994) membagi iklim organisasi dalam tiga bagian atau pendekatan, yaitu:

1. Multiple Measurement - Organizational Approach, yaitu iklim organisasi dipandang sebagai serangkaian karakteristik deskriptif dari organisasi yang mempunyai tiga sifat (tetap selama periode tertentu, berbeda antara organisasi satu dengan organisasi lainnya, dan mempengaruhi perilaku orang yang berada dalam organisasi tersebut;

2. Perseptual Measurement-Organizational Attribute Approach, yaitu iklim organisasi dipandang sebagai atribut organisasi;

3. Perseptual Measurement - Individual Approach, yaitu iklim organisasi dipandang sebagai serangkaian ringkasan atau persepsi global yang mencerminkan sebuah interaksi antara kejadian yang nyata dalam organisasi dan persepsi terhadap kejadian tersebut.

Iklim organisasi oleh Litwin dan Stringer (1968), dijabarkan atau diukur melalui lima dimensi indikator meliputi: tanggung jawab, identitas, kehangatan, dukungan, dan konflik. Menurut Higgins (1994) ada empat prinsip faktor-faktor yang mempengaruhi atau membentuk iklim, yaitu: pimpinan, tingkah laku karyawan, tingkah laku kelompok kerja, dan faktor eksternal organisasi.

\section{c. Kepuasan Kerja}

Kepuasan kerja didefinisikan sebagai suatu sikap umum terhadap pekerjaan; selisih antara banyaknya ganjaran yang diterima pekerja dan yang mereka yakini seharusnya diterima. Menurut Wexley dan Yukl (1977) teori-teori tentang kepuasan kerja ada tiga macam, yaitu:
1. Teori Perbandingan Intrapersonal.

Kepuasan atau ketidakpuasan yang dirasakan oleh individu merupakan hasil dari perbandingan atau kesenjangan yang dilakukan oleh diri sendiri terhadap berbagai macam hal yang sudah diperolehnya dari pekerjaan dan yang menjadi harapannya;

2. Teori Kesetaraan / Equity Theory. Seseorang akan merasa puas atau tidak puas tergantung apakah ia merasakan adanya keadilan atau tidak atas suatu situasi;

3. Teori Dua - Faktor. Kepuasan dan ketidakpuasan kerja merupakan dua hal yang berbeda.

Menurut Hasibuan (2009) kepuasan kerja karyawan dipengaruhi oleh faktor-faktor seperti balas jasa yang adil dan layak, penempatan yang tepat sesuai dengan keahlian, berat ringannya pekerjaan, suasana dan lingkungan kerja, peralatan yang menunjang pelaksanaan pekerjaan.sikap pimpinan dalam kepemimpinannya dan sikap pekerjaan monoton atau tidak.

Pengukuran kepuasan kerja seperti yang diungkapan oleh Robbins (2007), ada dua pendekatan yang dapat digunakan yaitu; 1) metode penilaian tunggal yang dikaji secara umum 2). metode penilaian penyajian yang terdiri atas sejumlah aspek pekerjaan.

\section{d. Hubungan Antara Budaya Organisasi dan Iklim Organisasi terhadap Kepuasan Kerja dari Anggota Organisasi}

Baik budaya organisasi dan iklim organisasi mempunyai pengaruh terhadap kepuasan kerja anggotanya, karena keduannya menentukan suatu landasan berpikir, cara bekerja, dan pengembangan dari suatu organisasi dalam mencapai tujuannya. Budaya organisasi (yang merupakan variabel bebas) akan mempengaruhi cara pandang anggota organisasi dalam menyikapi sesuatu dan juga memacu setiap anggota organisasi untuk mencapai tujuan organisasi. Sedangkan iklim organisasi adalah suatu evolusi dari interaksi yang terjadi ketika suatu budaya organisasi menemui suatu perubahan di lingkungannya, sehingga secara tidak langsung iklim organisasi adalah variabel dependen dari budaya organisasi, akan tetapi iklim organisasi juga bertindak sebagai variabel bebas yang mempengaruhi kepuasan kerja anggota organisasi. 


\section{KERANGKA KONSEPTUAL DAN HIPOTESIS}

Hubungan antar konsep yang mendasari penelitian ini, yaitu: Budaya organisasi, iklim organisasi, dan kepuasan kerja karyawan seperti yang digambarkan pada model berikut:

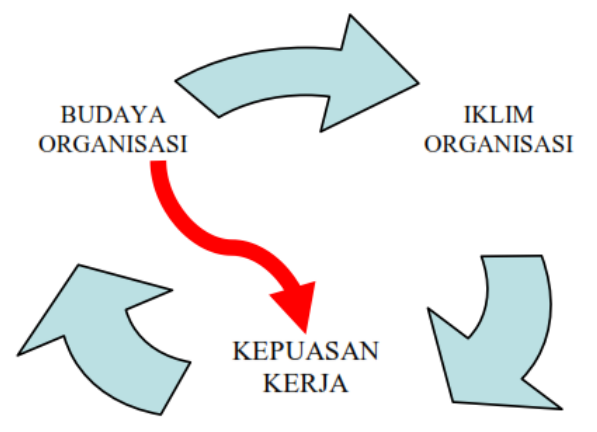

Gambar 1. Model Konseptual

Berdasarkan model konseptual yang dipaparkan, maka dapat menghasilkan pendugaan bahwa variabel budaya organisasi berpengaruh secara langsung terhadap iklim organisasi, iklim organisasi berpengaruh langsung terhadap kepuasan kerja, budaya organisasi berpengaruh secara tidak langsung terhadap kepuasan kerja, dan kepuasan kerja secara langsung akan mempengaruhi budaya organisasi, maka model hipotesis dalam penelitian ini adalah sebagai berikut:

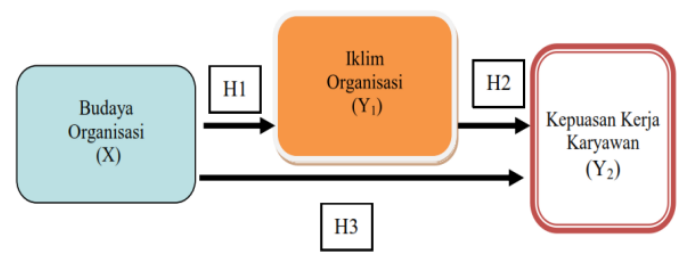

Gambar 2. Model Hipotesis

Berdasarkan Gambar 2, dapat dijabarkan hipotesis sebagai berikut:

H1: Budaya Organisasi berpengaruh signifikan terhadap Iklim Organisasi

$\mathrm{H} 2$ : Iklim Organisasi berpengaruh signifikan terhadap kepuasan kerja

H3: Budaya Organisasi berpengaruh signifikan terhadap kepuasan kerja

\section{METODE PENELITIAN}

Penelitian ini menggunakan rancangan penelitian survey yaitu penelitian yang bertujuan memperoleh data berupa opini, sikap, dan persepsi karyawan mengenai budaya organisasi dan iklim organisasi terhadap kepuasan kerja. Penelitian ini termasuk dalam jenis penelitian eksplanatory research, yaitu jenis penelitian yang berupaya menjelaskan hubungan kausal antara variabel-variabel melalui pengujian hipotesis.

Lokasi Penelitian adalah koperasi Cipta Sejahtera yang beralamatkan di Jalan Raya Orooro Dowo 49 dan Jalan Raya Sawojajar 157 Malang Jawa Timur. Populasi dari penelitian ini adalah seluruh karyawan tetap koperasi Cipta Sejahtera di Kota Malang. Penelitian ini menggunakan seluruh anggota populasi karena anggota populasi relatif kecil.

Pengumpulan data dalam penelitian ini dengan cara menyebarkan kuisioner kepada karyawan koperasi Cipta Sejahtera di Kota Malang sebagai data primer dan catatan/laporan dari manajemen koperasi sebagai data sekunder.

Variabel eksogen atau independen pada penelitian ini adalah budaya organisasi (X). Sedangkan variabel endogen atau dependen adcalah iklim organisasi $\left(\mathrm{Y}_{1}\right)$ dan kepuasan kerja $\left(\mathrm{Y}_{2}\right)$. Instrumen masing-masing butir pernyataan diukur menggunakan skala Likert lima poin. Angka 1 sampai dengan 5 merupakan jenjang skor setiap pernyataan. Artinya jika responden untuk suatu pernyataan memilih jawaban sangat setuju (SS), maka skor jawaban tersebut 5 .

Variabel budaya organisasi, iklim organisasi, dan kepuasan kerja telah memenuhi asumsi valid dan reliabel. Analisis yang digunakan adalah analisis deskriptif dan pengolahan data dengan analisis jalur (path analysis).

\section{HASIL PENELITIAN DAN PEMBAHASAN}

Variabel penelitian dalam penelitian ini, adalah budaya organisasi, iklim organisasi, dan kepuasan kerja karyawan digambarkan dengan metode statistik deskriptif, sedangkan untuk menguji digunakan analisis jalur (path analysis) dan uji-t untuk menguji hipotesis penelitian.

Analisis statistik deskriptif bertujuan untuk menggambarkan statistik berupa frekuensi, presentase, maupun rata-rata (mean) masingmasing skor untuk setiap item pada seluruh variabel penelitian.

Budaya organisasi (X) adalah suatu nilai dan keyakinan yang terkandung dalam suatu organisasi yang mana telah mengakar dan mempengaruhi segala tindakan anggota 
organisasi. Indikator yang dapat dijadikan alat ukur terhadap budaya organisasi adalah indikator nilai $\left(\mathrm{X}_{1}\right)$ dan indikator keyakinan $\left(\mathrm{X}_{2}\right)$. Item-item dari kedua indikator tersebut adalah mematuhi pimpinan $\left(\mathrm{X}_{1.1}\right)$, mengutamakan kepentingan organisasi $\left(\mathrm{X}_{1.2}\right)$, menjalankan tugas dengan baik $\left(\mathrm{X}_{2.1}\right)$, dan menjalankan peraturan perusahaan $\left(\mathrm{X}_{2.2}\right)$.

Iklim organisasi $\left(\mathrm{Y}_{1}\right)$ adalah adalah kesamaan persepsi para anggota organisasi tentang sikap dan kebutuhan, tentang tugas dan pekerjaan, serta hubungan manusia dengan lingkungan. Indikator yang dapat dijadikan alat ukur adalah hubungan pimpinan dengan bawahan $\left(\mathrm{Y}_{1.1}\right)$ dan Suasana lingkungan kerja $\left(\mathrm{Y}_{1.2}\right)$. Kedua indikator tersebut mempunyai item-item sebagai berikut; pimpinan memperhatikan karyawan $\left(\mathrm{Y}_{1.1 .1}\right)$, puas dengan keputusan pimpinan $\left(\mathrm{Y}_{1.1 .2}\right)$, memberi kritik yang membangun $\left(\mathrm{Y}_{1.2 .1}\right)$, menghargai orang lain $\left(\mathrm{Y}_{1.2 .2}\right)$, dan membantu rekan kerja yang mengalami kesulitan dalam pekerjaan $\left(\mathrm{Y}_{1.2 .3}\right)$.

Kepuasan kerja $\left(\mathrm{Y}_{2}\right)$ merupakan suatu rasa yang dirasakan oleh anggota suatu organiasasi atau karyaan suatu perusahaan yang menyebabkan mereka bertahan (bekerja) dalam organisasi atau perusahaan. Indikator yang dapat dijadikan alat ukur adalah indikator ektrinsik $\left(\mathrm{Y}_{2.1}\right)$ dan indikator intrinsik $\left(\mathrm{Y}_{2.2}\right)$ dengan item-item pertanyaan debagai berikut; rekan kerja menyenangkan dan sangat membantu $\left(\mathrm{Y}_{2.1 .1}\right)$, upah yang diterima karyawan memuasakan $\left(\mathrm{Y}_{2.1 .2}\right)$, organisasi memberikan kesempatan kepada karyawan untuk maju $\left(\mathrm{Y}_{\text {2.2.1 }}\right)$, dan sangat puas dengan pekerjaan $\left(\mathrm{Y}_{2.2 .2}\right)$.

\section{a. Analisis Deskriptif}

- Dari 60 karyawan koperasi Cipta Sejahtera, karyawan dengan jenis kelamin laki-laki sebanyak 47 orang $(78,3 \%)$ dan perempuan sebanyak 13 orang $(21,7 \%)$;

- Karyawan koperasi Cipta Sejahtera berpendidikan SMA dan sederajat sebanyak 30 orang (50\%) diikuti pendidikan diploma (D1, D2, D3) sebanyak 25 orang $(41,6 \%)$ dan sarjana S1 sebanyak 5 orang $(8,4 \%)$;

- Karyawan dengan usia produktif mendominasi sebesar total $91,4 \%$ untuk sebaran usia produktif $20-35$ tahun sedangkan usia 36 - 40 tahun sebanyak $16,6 \%, \quad 41 \quad-45$ tahun sebanyak $6,6 \%$ dan > 45 Tahun sebanyak $1,6 \%$;
- Masa kerja hampir separuh karyawan adalah rentang waktu $4-5$ tahun yaitu sebanyak $41,6 \%$, berturut-turut dikuti oleh rentang waktu 2-3 tahun sebanyak $33,3 \%$, rentang $>5$ tahun sebanyak $16,6 \%$ dan 0-1 tahun sebanyak 8,3\%;

- Menjalankan tugas dan menjalankan peraturan perusahaan paling mempengaruhi budaya organisasi dimana masing-masing rata-rata skor jawaban 4,53 dan 4,4. Dari rerata nilai budaya organisasi sudah cukup baik dengan nilai rerata 4,23 ;

- Item puas dengan keputusan yang diambil oleh pimpinan $\left(\mathrm{Y}_{1.1 .2}\right)$ dan item menghargai orang lain yang memahami pekerjaan karyawan $\left(\mathrm{Y}_{1.2 .2}\right)$ dengan rata-rata skor jawaban 4,06. Dari rerata nilai iklim organisasi sudah cukup baik dengan nilai rerata 3,98 ;

- Dari deskripsi diatas dapat dilihat item Upah yang diterima memuaskan $\left(\mathrm{Y}_{2.1 .2}\right)$ dan sangat puas dengan pekerjaan $\left(\mathrm{Y}_{2.2 .2}\right)$ mempengaruhi kepuasaan kerja dengan rata-rata skor jawaban 3,93. Dari rerata nilai kepuasan kerja sudah cukup baik dengan nilai rerata 3,88 .

\section{b. Analisis Jalur}

\section{Pengujian Asumsi}

Asumsi yang diuji dalam penelitian ini adalh asumsi normalitas dan linieritas. Hasil uji normalitas data, nilai critical ratio skewness variabel $\mathrm{X}_{1.1}$, sebesar $0.000, \mathrm{X}_{1.2}$ sebesar -1.369, $\mathrm{Y}_{1.1}$ sebesar $0.408, \mathrm{Y}_{1.2}$ sebesar -1.255, $\mathrm{Y}_{2.1}$ sebesar 0.166, dan $\mathrm{Y}_{2.2}$ sebesar -0.054, memenuhi asumsi normalitas disebabkan nilai critical ratio skewness berada di rentang -2.58 sampai dengan +2.58 . Sedangkan dari hasil pengujian terhadap hubungan antara variabel tak bebas dengan variabel bebasnya menghasilkan nilai signifikansi sebesar 0.000.Dengan demikian asumsi linieritas telah terpenuhi.

\section{Pengujian Hipotesis Koefisien Jalur}

Hubungan variabel Budaya Organisasi

(X) dengan Iklim Organisasi ( $\left.\mathrm{Y}_{1}\right)$ menunjukkan nilai koefisien jalur 1.834 yang berarti kedua variabel tersebut memiliki hubungan positif dengan $p$-value kurang dari 0.000 yang berarti terdapat hubungan yang signifikan. 
Hubungan variabel iklim organisasi (Y1) dengan Kepuasan Kerja (Y2) menunjukkan nilai koefisien jalur sebesar 0.052 yang berarti kedua variabel tersebut memiliki hubungan negatif dengan $p$-value sebesar $0.875>0.05$ yang berarti tidak terdapat hubungan yang signifikan.

Hubungan variabel Budaya Organisasi (X) dengan Kepuasan Kerja (Y2) menunjukkan nilai koefisien jalur sebesar 1.032 yang berarti kedua variabel tersebut memiliki hubungan positif dengan $p$-value sebesar $0.127>0.05$ yang berarti tidak terdapat hubungan yang signifikan.

\section{KESIMPULAN DAN SARAN \\ a. Kesimpulan}

Semakin bagus nilai budaya organisasi maka semakin bagus pula nilai iklim organisasi. dengan nilai integritas yang tinggi maka tugas yang diberikan organisasi kepada karyawan dapat terselesaikan dengan baik,integritas juga akan mempengaruhi ketaatan karyawan untuk menjalankan keputusan yang diambil oleh pimpinan, dan menumbuhkan sikap yang saling menghargai baik antar sesama karyawan, maupun karyawan dengan pimpinan.

Semakin bagus nilai iklim organisasi maka semakin tidak berarti bagus pula nilai kepuasan kerja. Hal ini dapat terjadi dikarenakan kemajemukan karyawan baik dalam segi usia, tingkat pendidikan, dan lama masa kerja. Kemajemukan karyawan tersebut kadangkala membuat suatu gap atau batasan untuk dapat membaur dengan yang lain.

Semakin bagus nilai budaya organisasi maka semakin bagus pula nilai kepuasan kerja. item menjalankan peraturan perusahaan dengan baik pada akhirnya berimbas kepada pemahaman karyawan untuk mencintai pekerjaan sehingga setiap pekerjaan yang dilakukan karyawan dapat menambah wawasan dan pengembangan diri mereka. Setiap pekerjaan yang dapat terselesaikan dengan baik akan memperoleh penghargaan yang layak dari pimpinan dan itu ditunjukan pada item upah yang diterima memuaskan.

\section{b. Saran}

Budaya organisasi perlu dipertahankan dan dipupuk dengan baik karenakan akan dapat menjaga iklim organisasi dan kepuasan kerja dengan baik. Terutama pada poin item disiplin waktu dalam bekerja dan mematuhi peraturan perusahaan yang memiliki skor tertinggi pada variabel budaya organisasi.

Perlu ditingkatkan lagi iklim organisasi yang lebih baik yang mana akan dapat menciptakan suasan kerja yang harmonis, sehingga target perusahaan dapat tercapai.

Adanya keterbatasan dalam penelitian ini memberi ruang kepada peneliti selanjutnya untuk lebih mengembangkan model penelitian yang berkaitan dengan variabel-variabel lain yang mempengaruhi kepuasan kerja karyawan dengan lokasi penelitian yang lebih luas sehingga dapat menambah khasanah ilmu pengetahuan khususnya di bidang sumber daya manusia.

\section{DAFTAR PUSTAKA}

Hasibuan M. 2009. Manajemen Sumber Daya Manusia. Bumi Aksara. Jakarta.

Higgins, J. M. 1994. The Management Challenge. Second Edition. Macmillan. New York.

Robbins Stephen P. 2002. Essentials of Organizational Behavior (Terjemahan). Edisi Kelima. Jakarta: Erlangga.

Robbins, Stephen P. 2007. Organizational Behavior. 11 th edition. Pearson Prentice Hall. New Jersey.

Robbbins dan Judge. 2007. Perilaku Organisasi, Buku 1 dan 2. Salemba Empat. Jakarta.

Toulson, P. Dan Mike, Smith. 1994. "The Relationship between Organizational Climate and Employee Perceptions of Personnel Management Practices". Journal of Public Personnel Management. Vol 23, Issue 3. (Fall). 453-469.

Wexley, K.N. Dan Yukl, G.A. 1977. Organizational Behavior and Personnel Psychology. Richard D. Irwin: Home wood. Illnois. 